\title{
Correction to: Cellular mechanisms responsible for cell-to-cell spreading of prions
}

\author{
Didier Vilette $^{1} \cdot$ Josquin Courte ${ }^{2,4} \cdot$ Jean Michel Peyrin ${ }^{2} \cdot$ Laurent Coudert $^{3} \cdot$ Laurent Schaeffer $^{3} \cdot$ Olivier Andréoletti $^{1}$. \\ Pascal Leblanc ${ }^{3}$
}

Published online: 11 June 2018

(c) Springer International Publishing AG, part of Springer Nature 2018

\section{Correction to: Cellular and Molecular Life Sciences https://doi.org/10.1007/s00018-018-2823-y}

In the original publication, part of acknowledgement text was missing. The complete acknowledgement section should read as follows.

Acknowledgements We thank Marie-Christine Miquel for comments and for carefully reading the manuscript. PL received the support of the Association pour la recherche sur la SLA (ARSLA), the NeuroDis Fundation and the AFM. $\mathrm{LC}$ received for his $\mathrm{PhD}$ an ARC2 "Qualité de vie et Viellissement" Grant from the région Auvergne Rhône-Alpes.

The original article can be found online at https://doi.org/10.1007/ s00018-018-2823-y.

Didier Vilette

d.vilette@envt.fr

$\triangle$ Jean Michel Peyrin

jean-michel.peyrin@upmc.fr

$\triangle$ Pascal Leblanc

pascal.leblanc@univ-lyon1.fr

1 UMR1225, INRA, ENVT, Ecole Nationale Vétérinaire, 23

Chemin des Capelles, Toulouse, France

2 Neurosciences Paris Seine, UMR8246, Inserm U1130, IBPS, UPMC, Sorbonne Universités, 4 Place Jussieu, 75005 Paris, France

3 Insitut NeuroMyoGène, CNRS UMR5310, INSERM U1217, Faculté de Médecine Rockefeller, Université Claude Bernard Lyon I, 8 Avenue Rockefeller, 69373 Lyon Cedex 08, France

4 Laboratoire Physico Chimie Curie, UMR168, UPMC, IPGG, Sorbonne Universités, 6 Rue Jean Calvin, 75005 Paris,

France 